\title{
Receptor Activity-Modifying Protein 2
}

National Cancer Institute

\section{Source}

National Cancer Institute. Receptor Activity-Modifying Protein 2. NCI Thesaurus. Code C127152.

Receptor activity-modifying protein $2(175 \mathrm{aa}, \sim 20 \mathrm{kDa})$ is encoded by the human RAMP2 gene. This protein is involved in the membrane localization of calcitonin gene-related peptide type 1 receptor. 